International Journal of Linguistics, Literature and Translation

ISSN: 2617-0299 (Online); ISSN: 2708-0099 (Print)

DOI: $10.32996 / \mathrm{ijllt}$

Journal Homepage: www.al-kindipublisher.com/index.php/ijltt

IJLLT

\title{
Factors and Problems Affecting Reading Comprehension of Undergraduate Students
}

\author{
Dr. Sawitri Suwanaroa \\ Faculty of Business Administration and Liberal Arts, Rajamangala University of Technology Lanna Tak, Thailand
}

$\square$ Corresponding Author: Dr. Sawitri Suwanaroa, E-mail: sawitri_75@yahoo.com

\section{ARTICLE INFORMATION}

Received: 03 October 2021

Accepted: 14 November 2021

Published: 07 December 2021

DOI: $10.32996 /$ ijltt.2021.4.12.3

\section{KEYWORDS}

Reading comprehension,

influential factors, student attitude

\section{ABSTRACT}

This study aims to investigate factors affecting reading comprehension problems of 2nd, 3rd, and 4th-year students of English for International Communication (EIC) at Rajamagala University of Technology Lanna Tak. The study's objectives were 1) to examine the reading comprehension problems found most in $2 \mathrm{nd}, 3 \mathrm{rd}$, and 4 th year EIC students; and 2) to investigate the main factors influencing the reading problems that in turn, greatly affected the reading competence of $2 \mathrm{nd}$, 3rd, and 4th-year students of EIC and how they cope with these problems. In this study, $77 \mathrm{EIC}$ students demonstrated reading problems and factors which were adopted from Manutsawee (2015). The results showed that these students reflected different perceptions related to their reading problems and the factors that had an impact on their reading problems. The reading problems for the 2 nd year EIC students were related to grammar, vocabulary, understanding, and personal experience with an average of 3.50, $3.43,3.25$, and 3.25, respectively. Meanwhile, the 3rd year students showed that they had difficulty with vocabulary (3.19) and grammar (3.10), with understanding and personal experience having the same average score (3.00). Finally, the 4th year students' reading problems were in the area of vocabulary (3.50), understanding and grammar (3.25), and personal experience (3.14). Moreover, the factor that affected EIC students' reading problems the most was identified as follows. The 2 nd year students perceived students' attitude as the most influential factor at 3.91. However, the 3rd year students thought classroom teaching had the greatest impact on their reading problems at 3.79. Finally, the student's attitude was also the most influential factor, at 3.91 , for the 4th year students.

\section{Introduction}

Reading is an essential and useful skill in education, knowledge, occupation, and practice, especially in today's world where information about reading will help us. It can be said that reading is essential to life because reading is not just cooking, words and commands. Rather, it is a tenant of knowledge because it helps us understand the meaning, character, and cause of new ideas from the old ways. As Pennsri, Rangsri, and Yangkul (1987) said, reading only provides the meaning of calmness of the alphabet. But this must not mean reading as well the results of the strange things by bringing the original meanings to the competition and to find out how less accurate it is. Reading is still considered necessary for achieving success in one's life, as Richek, (1996) has commented that children with poor reading ability tend to have a level of self-esteem, which in turn affects their higher education prospects. Due to the importance of this foreign language, the Ministry of Education has designated the English language to be used in all classes to strengthen the foundation, build potential to think and work creatively and prepare for students to be in line with the information age society, helping students to be visionary, able to develop ideas and look at the wider world. When students continue to study English from primary school to secondary level, they will have the knowledge and ability to receive and send messages. There can be a culture of using language, conveying ideas, knowledge, understanding, feelings, and their views to exchange information and experiences that are beneficial to self-development and society (Department of Academic Affairs,2008). Submission of materials, exposure, and reading process is considered to be a key in (communication and receiving system). The goal of reading will help the readers to understand the subject and the meaning of the story which caused ideas to be considered as the selection of information (Samli Ruksutee, 2010, p.1). The years 2009-2018 were the decade of countrywide reading. This also

Copyright: (c) 2021 the Author(s). This article is an open access article distributed under the terms and conditions of the Creative Commons Attribution (CC-BY) 4.0 license (https://creativecommons.org/licenses/by/4.0/). Published by Al-Kindi Centre for Research and Development, London, United Kingdom. 
included having a reading promotion committee to create a lifelong learning society because reading books makes readers knowledgeable, enhancing the potential of life. It is considered an important human resource development that directly affects the development of the country. The year 2015 was the year of the ASEAN Community, and it became very important that the government and the Ministry of Education develop the reading competencies of students at various levels to have a strong reading foundation (National Statistical Office, 2015, P. 16). In the present study, the major reading problems of EIC students were explored. This included 4 problems of reading comprehension: 1) Understanding problems; 2) Personal experience problems; 3) Vocabulary problems, and 4) Grammar problems. Furthermore, this study investigated factors influencing reading problems that EIC students at each level encountered in their backgrounds. These were factors related to the following: 1) Students' attitudes; 2) Family support; and 3) Teaching and learning in the classroom.

\subsection{The rationale of the study}

English reading is important, but research constantly reflects that students' English reading ability is at the problem level. Naowarat Noomura (1991) stated that students' reading capacity is also low, particularly understanding the reading material, where students are not able to sort events and comprehend the importance of readable stories. English reading achievement of Thai students is poor, and it will take many years to learn English due to a lack of knowledge in reading and understanding (Malinee Chantavimol, 1992). According to Damnet's (1998) study, most English reading problems of Thai students are caused by a lack of training in reading strategies. In addition, the research results of Chanida Srisongmuang (2003) supported that Thai students at this educational level still have problems with reading strategies, such as reading a chapter and understanding the importance of the script. Most students cannot understand the importance of reading according to the report of the Ministry of Education (2008) which indicates that the student's reading ability is not satisfactory. Students have trouble understanding. The reading text makes them unable to grasp the ideas. From the above research, students had problems in reading English for a long time which had several causes.

\subsection{Objectives of the study}

1. To examine the reading comprehension problems found most in 2nd, 3rd, and 4th-year students in EIC.

2. To investigate the main causes of the reading problems that greatly affect the reading competence of $2 \mathrm{nd}$, $3 \mathrm{rd}$, and 4 thyear students in EIC.

\subsection{Research questions}

1. What are the reading comprehension problems found most in 2nd, 3rd, and 4th-year students in EIC?

2. What are the main factors causing the reading problems for $2 \mathrm{nd}, 3 \mathrm{rd}$, and 4 th-year students of EIC?

\subsection{Significance of the study}

The results of this study can be used as preliminary information for those interested in researching factors influencing problems of reading articles or related matters to promote and develop learners in English reading for EIC students in the 2nd, 3rd, and 4th years which allows students to develop their reading more accurately.

\section{Literature Review}

\subsection{Definition of Reading Comprehension}

The meaning of reading cannot be explained in only a few words. The topic of the meaning of reading is a matter of deep research and analysis. However, the researchers have tried to define and explain the meaning of reading through the following definitions.

According to Surasawadee Ajnontla (2006), reading is a complex process and requires communication between the writer and the reader by interpreting the symbolic characters using various skills in sound, linguistics, and mechanics. The way to solve the problem comes out into an idea based on the reader's original experience to create reading comprehension. Banlue Phueksawan (1989) gave the meaning of reading as the use of the ability to combine letters and pronunciation into words or sentences. To convey the meaning to the reader, one must use observation, word memory, intelligence, and previous experience in interpreting or transcribing to a better understanding of the subject. This must be carried out in steps and continuous processes to take the results of the reading and evaluate the concepts and practices. Sanit Tangtawi (1986) gives the meaning of reading as follows: reading means the interpretation of words or ideas, and then bringing those ideas into good uses of the letters which are just symbols instead of words. Therefore, the heart of reading is to understand the meaning of the words that appear in a text.

The study by William (1993) discussed the meaning of reading. as a process in which the reader sees and understands the passage. This means the readers must understand everything they read and the finer details of the content and not just the letters, words, or sentences. To read and understand, the reader must know the writing system and the language, as well as the ability to interpret word relations at the sentence level and knowledge of cultural traditions and customs. In addition, readers must have a reason and style of reading. Harris and Sipay (1990) defined reading as a form of communication that exchanges ideas and news between 
the author and the reader. The author will express their opinions on paper in the language according to the writing style of each person. The reader will try to read the meaning of the author.

The works of Anderson (1985) mentioned that reading is the process of searching for the meaning on many levels from characterlevel language structure to the level of reading for comprehension caused by the interaction between the content and the structure of the story and the original knowledge of the reader, which will help create assumptions about the subject being read. Readers who are fluent in reading can predict and can infer information from reading.

Based on the meaning of reading above, it can be concluded that reading refers to the process of communicating the meaning that leads to learning. The reader must try to understand the meaning of what is read by translating, interpreting, and expanding the characters that appear in reading into thoughts and use those ideas for good use based on the readers' original experience.

\subsection{Reading for Comprehension}

According to Samut Senchaowanich (1987), understanding is the ability to infer information or meaning that is desired from reading as efficiently as possible. This understanding is related to education and experiences in many areas of each person and is considered as one of the important elements of reading.

The works of Bond and Tinker (1979) stated that readers' comprehension requires the following components:

1. Understand the meaning of the word - understanding the meaning of the vocabulary will help to interpret the sentence well.

2. Understand each unit by reading words by word that will not be an obstacle to understanding because of the lack of continuity; therefore, the students must be trained to read the text as a unit of their thoughts.

3. Understand sentences (sentence comprehension) - when readers can relate the sub-concepts to the sentence, they can see the relationship between words in the sentence as well.

4. Understand the paragraph - the reader must be able to tell the main points of each sentence and then connect the important points. Therefore, readers should learn the genre.

5. Understand all content (comprehension of larger units) - to understand the whole story, readers must know the relationship between important texts in each section and the order of the ideas of the story and must know that each type of script has a different text structure.

According to Duffy and Roehler (1993), reading comprehension means being able to correctly interpret the meaning of the readings as well as being able to understand that meaning. Based on the reader's original knowledge base, reading comprehension can be achieved when the reader relates his previous experience with the written text.

In line with Gray (1960), there are three levels of understanding: reading 'the lines', reading 'between the lines', and reading 'beyond the lines'. The first refers to the literal meaning of a text, the second to inferred meanings, and the third to readers' critical evaluations of a text.

The works of Rosenblatt (1983) interpreted reading differently and interestingly. She said when people read, they construct the meaning of a text. In other words, people create their mental version of what they read. The readers, the material, and the reading situation all contribute to the meaning that is constructed.

\subsection{Factors influencing problems with reading comprehension}

According to Richek (1996), children who lack reading ability tend to have low self-esteem which will affect their opportunities in future job searches. Reading is one of the language learning skills, especially for foreign languages, which is often a problem for most learners. In Thailand, English is considered one of the important foreign languages and is widely used to communicate with foreigners each year. Many foreigners who come to Thailand for business or tourism use English as an international language. Therefore, learning English is an important thing especially for Thai people.

Reading is not just spelling and pronunciation, but it is also a source of knowledge. It is a tool to help us understand the meaning of the alphabet and create new ideas from previous experiences. It lets a reader know not only the meaning of the symbols of the letters but also the interpretation at the same time. They must be able to evaluate the readings by applying existing experience, and deciding how accurate and reasonable it is.

Reading skills should be cultivated for learners to be able to read verses and think critically. From the research of Jintana (2005), it was found that reading can have many problems; that is, students cannot read, understand, and grasp the idea. Consistent with the research of Chanida (2003), it was found that Thai children at all levels still have reading problems, such as reading without 
understanding. They cannot grasp the importance, cannot transfer meaning, cannot analyze content, and cannot summarize ideas. In essence, it does not result in relatively low levels on national tests. Low academic achievement makes students have a poor attitude towards learning English and lose interest in studying.

Reading for understanding from another perspective means Understanding the direct and implicit meaning to capture the importance and details of what is read expressing opinions and arguments about the subject being read and writing the conceptual framework, concept map, and summary. It is therefore an important goal of curriculum development and reading comprehension.

Studying reading for understanding abroad is very important. because a person must be able to understand what they are reading first. Therefore, data can be processed from other forms of reading such as analysis, and criticism (Hock and Mellard, 2005).

University of Kansas researchers have found that an effective way to develop reading comprehension ability, especially in adulthood, is to ask questions (self-questioning) and use visuals (visual imagery). The method or technique of teaching reading that is consistent with the findings of this research is using a diagram organizer or graphic organizer and a variety of forms for the development of reading ability for comprehension through the development of various processes/skills. There is no need to complete all aspects or all components at once. How to use or not to use them naturally depends on the learners and the characteristics of the text they read including the purpose of that reading.

Students who are good at learning will help students who are weak to learn. Those students will learn without anxiety but with enthusiasm for reading verses and will love to study more which will result in higher reading achievement.

The researcher foresaw that the problems include students being unable to read the significance, interpret the story, read or analyze the article, and convey the story read for others to understand. In addition, during an academic session, the researcher observed that most students lack enthusiasm for reading and at some times, the learners secretly use a translation program to interpret the meaning of the article, causing the student to practice reading comprehension skills with a lack of analytical and summary skills. This is an important factor that results in the English reading achievement of students being below the criteria.

The works of Supaporn Yimwilai (2008) studied the reading abilities and problems of English-major students in the Department of Western Languages, Faculty of Humanities, Srinakharinwirot University, and compared the reading abilities of English-major students in a BA program and those in a B. Ed program.

\subsection{Previous Research Related to Factors Influencing Reading Comprehension Problems}

Raviwan Chaiwasu (1988) researches English language learning problems of students majoring in English for their bachelor's degree in the Faculty of Education.

According to Pen Sri Rangsangyangkul (1987), reading is not only letting the reader know the meaning of the symbol of the letters but having to interpret it at the same time. They must be able to evaluate the readings by applying existing experience and deciding how accurate and reasonable it is. Similarly, Sunee Sanphak (2009) says some English language teachers teach with an emphasis on translation, memorization of words, and grammar rules which do not promote thinking skills and prevent students from developing reading comprehension.

In line with Hock and Mellard (2005), University of Kansas researchers, an effective way to develop reading comprehension ability, especially in adulthood, is to ask questions.

According to Richek (1996), children who lack reading ability tend to have low self-esteem which will affect opportunities in future job searches. Reading is one of the language learning skills, especially in foreign languages, which is often a problem for learners. In Thailand, English is considered one of the important foreign languages and is widely used to communicate with foreigners.

\section{Research Methodology}

\subsection{Participants in the study}

The participants in the study were 77 English for International Communication students (EIC) at the Rajamangala University of Technology Lanna, Tak campus, in Tak province, Thailand. There were 3 groups of participants including 282 nd year students, 21 3rd year students, and 284 th year students. The participants were aged between 20 and 22 years old. The reason for choosing this sample group was that they are English major students who have studied reading courses and have been exposed to various kinds of written texts that they needed to cope with in their study.

Table 3.1 Numbers of English for International Communication students in the study

\begin{tabular}{|l|l|l|}
\hline Year level of students & Frequency (n) & Percentage (\%)
\end{tabular}




\begin{tabular}{|l|l|l|}
\hline Second-year students & 28 & 36.36 \\
\hline Third-year students & 21 & 27.28 \\
\hline Fourth-year students & 28 & 36.36 \\
\hline Total & 77 & 100.00 \\
\hline
\end{tabular}

Source: Faculty of Business Administration and Arts Student Registration Academic Year 2020.

\subsection{Research instruments}

Questionnaire related to reading problems and factors affecting EIC students' reading problems

The questionnaire used in the present study was Likert's' five scales and was adopted from Manatsawee (2015). It consists of 2 parts entitled as, first, reading problems with 4 question items and, second, three factors affecting students' reading problems with 7,4 , and 4 question items, respectively. In addition, the topics of the questionnaire related to reading problems and factors affecting students' reading problems on comprehension were listed as follows.

1.1 Questionnaires related to students' reading problems

\subsubsection{Understanding problem}

\subsubsection{Personal experience problem}

1.1.3. Vocabulary problem

1.1.4. Grammar problem

1.2 Questionnaires related to factors which affected students' reading comprehension problems

\subsubsection{Factors on students' attitudes}

\subsubsection{Factors on family support}

1.2.3. Factors on teaching and learning in the classroom

\subsection{Data collection}

The researcher tried out the instruments or questionnaire surveys with the sample group. Then, the questionnaire surveys were administered to the participants. After collecting data through the questionnaire surveys, data were analyzed using the SPSS program to obtain basic statistical results, to show the average priority of the respondents. Finally, the researcher analyzed the data and summarized the findings.

\subsection{Methods of data analysis}

The collected data was analyzed using two statistical formulas as follows.

3.4.1 The researchers collected and analyzed data for calculating quantitative data, which were Mean (X) and Standard Deviation (S.D.).

Table 3.3: Overall interpretation of students' reading problems and factors affecting reading problems.

Score rates $(\overline{\boldsymbol{X}})$ on students' reading problems and factors affecting reading problems

Interpretations 


\begin{tabular}{|l|l|}
\hline $1.00-1.80$ & Very Low \\
\hline $1.81-2.60$ & Low \\
\hline $2.61-3.20$ & Medium \\
\hline $3.21-4.20$ & High \\
\hline $4.21-5.00$ & Very High \\
\hline
\end{tabular}

Source: Moidunny K. 2009

\section{Results and Discussion}

This research aimed to study factors affecting reading comprehension problems of 2nd, 3rd, and 4th year EIC students at RMUTL Tak. The participants in the study were as follows:77 second, third, and fourth-year students of English for International Communication (EIC), Faculty of Business and Liberal Arts, Rajamangala University of Technology Lanna Tak. The investigator took the analyzed data and presented the results of the analysis by the two objectives of the proposed study, as follows.

Table 4.1: Frequency and Percentage for General Information

\begin{tabular}{|l|l|l|}
\hline Year level of students & Frequency (n) & Percentage (\%) \\
\hline Second-year students & 28 & 36.36 \\
\hline Third-year students & 21 & 27.28 \\
\hline Fourth-year students & 28 & 36.36 \\
\hline Total & 77 & 100.00 \\
\hline
\end{tabular}

Table 4.1 shows the year level of the respondents as follows: there were 28 second-year students (36.36\%), 21 third-year students (27.28\%), and 28 fourth-year students (36.36\%).

4.1.1 Examine the reading comprehension problems found most in 2nd, 3rd, and 4th year EIC students.

Table 4.2: Reading comprehension problems found most in 2nd year EIC students

\begin{tabular}{|l|l|l|l|}
\hline Reading problems & \multicolumn{1}{|c|}{$\bar{X}$} & S.D. & Interpretation \\
\hline $\begin{array}{l}\text { Understanding: I don't understand the content and can't identify } \\
\text { important points of content. }\end{array}$ & 3.25 & 0.75 & High \\
\hline $\begin{array}{l}\text { Personal experience: The content being read is not in my } \\
\text { knowledge area. }\end{array}$ & 3.25 & 0.75 & High \\
\hline $\begin{array}{l}\text { Vocabulary: I don't know words or expressions in the content I } \\
\text { read. }\end{array}$ & 3.43 & 0.79 & High \\
\hline $\begin{array}{l}\text { Grammar: I don't understand English sentence structure or } \\
\text { grammar. }\end{array}$ & 3.50 & 0.75 & High \\
\hline Reading problems in total & 3.36 & 0.02 & High \\
\hline
\end{tabular}

Table 4.2 revealed the reading problems of 2 nd year EIC students. The results showed that grammar was at the highest level among the three problems $\left(\mathrm{x}^{-}=3.50\right.$; S.D. $\left.=0.75\right)$, it also reflected that students were concerned about grammar as their most problematic factor.

Table 4.3: Reading comprehension problems found most in 3rd year EIC students 


\begin{tabular}{|l|l|l|l|}
\hline Reading problems & \multicolumn{1}{|c|}{$\overline{\boldsymbol{X}}$} & S.D. & Interpretation \\
\hline $\begin{array}{l}\text { Understanding: I don't understand the content and can't identify } \\
\text { important points of content. }\end{array}$ & 3.00 & 1.07 & Medium \\
\hline $\begin{array}{l}\text { Personal experience: The content being read is not in my } \\
\text { knowledge area. }\end{array}$ & 3.00 & 0.82 & Medium \\
\hline $\begin{array}{l}\text { Vocabulary: I don't know words or expressions in the content I } \\
\text { read. }\end{array}$ & 3.19 & 0.66 & Medium \\
\hline $\begin{array}{l}\text { Grammar: I don't understand English sentence structure or } \\
\text { grammar. }\end{array}$ & 3.10 & 0.81 & Medium \\
\hline Reading problems in total & 3.07 & 0.17 & Medium \\
\hline
\end{tabular}

Table 4.3 indicated the reading problems of the 3rd year EIC students. All four elements were at the medium level, but the vocabulary was at the highest interpretation among the three elements. It also reflected that 3rd year EIC students considered vocabulary: I don't know words or expressions in the content I read as their most concerned about reading problems. On the other hand, understanding and personal experience were at the lower interpretation which seemed to be their fewer concerns for reading problems.

Table 4.4: Reading comprehension problems found most in 4th year EIC students

\begin{tabular}{|l|l|l|l|}
\hline Reading problems & \multicolumn{1}{|c|}{$\bar{X}$} & Interpretation \\
\hline $\begin{array}{l}\text { Understanding: I don't understand the content and can't identify } \\
\text { important points of content. }\end{array}$ & 3.25 & 1.12 & High \\
\hline $\begin{array}{l}\text { Personal experience: The content being read is not in my } \\
\text { knowledge area. }\end{array}$ & 3.14 & 0.83 & Medium \\
\hline $\begin{array}{l}\text { Vocabulary: I don't know words or expressions in the content I } \\
\text { read. }\end{array}$ & 3.50 & 0.87 & High \\
\hline $\begin{array}{l}\text { Grammar: I don't understand English sentence structure or } \\
\text { grammar. }\end{array}$ & 3.25 & 0.87 & High \\
\hline Reading problems in total & 3.29 & 0.15 & High \\
\hline
\end{tabular}

Table 4.4 presents the 4th year EIC reading problems. Vocabulary was at the highest level $\left(x^{-}=3.50 ;\right.$ S.D. $\left.=0.87\right)$, followed by understanding and grammar were at a high level, as well as the personal experience was at the only medium level. These reflected that 4th year EIC students considered vocabulary as the most important problem of their reading comprehension followed by understanding and grammar, and personal experience was identified as the less problematic elements.

As shown in tables 4.2, 4.3, and 4.4, EIC students in each group perceived reading problems differently. In the 2 nd year group, grammar was seen to be their main reading problem $\left(x^{-}=3.50 ;\right.$ S.D. $\left.=0.75\right)$. Moreover, the 3rd year EIC students pointed out that vocabulary was their main reading problem $\left(x^{-}=3.19\right.$; S.D. $\left.=0.66\right)$. Finally, the group of 4 th year EIC students indicated that they have the most problems with vocabulary $\left(x^{-}=3.50 ;\right.$ S.D. $\left.=0.87\right)$.

4.1.2 Investigate the main factors of the reading problems that greatly affect the reading competence of 2 nd, 3rd, and 4 th-year students of EIC

Table 4.5: Factors of the reading problems that affect the reading competence of 2 nd year EIC students 


\begin{tabular}{|c|c|c|c|}
\hline 1. Factors of student's attitude & $\overline{\boldsymbol{X}}$ & S.D. & Interpretation \\
\hline 1. I like studying courses in English reading. & 4.00 & 0.81 & High \\
\hline $\begin{array}{l}\text { 2. I like reading English from different kinds of media such as } \\
\text { newspapers, magazines or the Internet. }\end{array}$ & 3.89 & 1.03 & High \\
\hline 3. I feel that ability to read English gives me a lot of benefits. & 4.42 & 0.92 & Very High \\
\hline 4. I can apply my knowledge to English reading. & 4.17 & 0.72 & High \\
\hline $\begin{array}{l}\text { 5. As I have a reading problem, I can employ reading techniques } \\
\text { to understand what I'm reading. }\end{array}$ & 3.71 & 0.65 & High \\
\hline $\begin{array}{l}\text { 6. I feel bored and lazy when I need to read any subject content } \\
\text { in English. }\end{array}$ & 3.32 & 1.09 & High \\
\hline $\begin{array}{l}\text { 7. I usually spend more leisure time on entertaining activities such } \\
\text { as watching TV, chatting online, going online on Facebook, or } \\
\text { playing games than reading. }\end{array}$ & 3.82 & 0.98 & High \\
\hline Students' attitude in total & 3.91 & 0.16 & High \\
\hline 2. Factors of family support & $\overline{\boldsymbol{X}}$ & S.D. & Interpretation \\
\hline 1. Everyone in my family supports me to read since I was young. & 3.75 & 1.00 & High \\
\hline 2. My parents keep telling me to read regularly. & 3.13 & 1.18 & Medium \\
\hline $\begin{array}{l}\text { 3. My parents realize the benefits of English, so they usually bring } \\
\text { home English books. }\end{array}$ & 3.10 & 0.91 & Medium \\
\hline $\begin{array}{l}\text { 4. My parents are interested in my English learning, especially } \\
\text { scores from English courses. }\end{array}$ & 3.37 & 1.09 & High \\
\hline Family support in total & 3.34 & 0.12 & High \\
\hline
\end{tabular}




\begin{tabular}{|l|l|l|l|}
\hline 3. Factors on teaching and learning in the classroom & \multicolumn{1}{|c|}{$\overline{\boldsymbol{X}}$} & S.D. & Interpretation \\
\hline $\begin{array}{l}\text { 1. I think that there should be more reading courses in the } \\
\text { curriculum of my faculty. }\end{array}$ & 3.79 & 0.73 & High \\
\hline $\begin{array}{l}\text { 2. I feel that I can practically use the contents from the reading } \\
\text { courses I studied. }\end{array}$ & 3.86 & 0.81 & High \\
\hline $\begin{array}{l}\text { 3. Activities in reading class are obsolete and not interesting. } \\
\text { 4. The instructor has good techniques in teaching reading, so it } \\
\text { makes students understand it and like reading. }\end{array}$ & 3.34 & 0.81 & High \\
\hline Teaching and learning in the classroom in total & 3.51 & 0.19 & High \\
\hline
\end{tabular}

Table 4.5 indicated factors related to students' attitudes of the 2nd year students. The statement number 3 ) I feel that ability to read English gives me a lot of benefits was at a very high level $\left(x^{-}=4.42 ;\right.$ S.D. $\left.=0.92\right)$ was at a very high level. Statement number 4) I can apply my knowledge to English reading was at a high level ( $x^{-}=4.17$; S.D. $\left.=0.72\right)$ was ranked as the second high level, and statement number 6) I feel bored and lazy when I need to read any subject content in English was at a high level $\left(x^{-}=3.32 ;\right.$ S.D. $=$ 1.09) was at the last ranking of a factor of students attitude. These represent that the 2nd year EIC students place their most attitude on benefits of reading English and they feel bored in case they need to read English content at a high level.

For factors related to family support, the 2 nd year EIC students showed that statement number 1) Everyone in my family supports me to read since I was young was at a high level $\left(x^{-}=3.75 ;\right.$ S.D. $\left.=1.00\right)$ was at the highest level, then statement number 4.) My parents are interested in my English learning, especially scores from English courses was at a high level $\left(x^{-}=3.37\right.$; S.D. $\left.=1.09\right)$ was the second-highest level of family support factor. Lastly, statement number 3) My parents realize the benefits of English, so they usually bring home English books was at a medium level $\left(x^{-}=3.10 ;\right.$ S.D. $\left.=0.91\right)$ was at medium level. These reflected that the 2 nd year EIC students mainly pointed out everyone in my family supports them to read is the most influential factor for their reading English ability. On the contrary, their parents bringing home English books was their less family support.

Based on factors related to teaching and learning in the classroom, statement number 2) I feel that I can practically use the contents from the reading course I studied was at a high level $\left(x^{-}=3.86\right.$; S.D. $\left.=0.81\right)$ was at the highest level. Then, statement number 1$)$ I think that there should be more reading courses in the curriculum of my faculty. I think that there should be more reading courses in the curriculum of my faculty was at a high level $\left(x^{-}=3.79\right.$; S.D. $\left.=0.73\right)$ and statement number 3 ) Activities in reading class are obsolete and not interesting was at a medium level $\left(x^{-}=3.03 ;\right.$ S.D. $=1.17$. These reflected that the 2 nd year EIC students recognized they can practically use contents from reading course they studied as the most significant factor and activities in reading class are obsolete and not interesting was their less significant factor on teaching and learning in the classroom.

Table 4.6: Factors related to reading problems that greatly affect the reading competence of 3rd year EIC students

\begin{tabular}{|l|l|l|l|}
\hline 1. Factors related to student's attitude & \multicolumn{1}{|c|}{$\overline{\boldsymbol{X}}$} & S.D. & Interpretation \\
\hline 1. I like studying English reading courses. & 3.14 & 1.06 & Medium \\
\hline $\begin{array}{l}\text { 2. I like reading English from different kinds of media such as } \\
\text { newspapers, magazines or the Internet. }\end{array}$ & 3.23 & 0.70 & High \\
\hline 3. I feel that ability to read English gives me a lot of benefits. & 4.19 & 1.03 & High \\
\hline $\begin{array}{l}\text { 4. I can apply my knowledge to English reading. } \\
\text { 5. As I have a reading problem, I can employ } \\
\text { reading techniques to understand what I'm reading. }\end{array}$ & 4.00 & 0.89 & High \\
\hline $\begin{array}{l}\text { 6. I feel bored and lazy when I need to read any subject content } \\
\text { in English. }\end{array}$ & 3.23 & 1.26 & High \\
\hline $\begin{array}{l}\text { 7. I usually spend more leisure time on entertaining activities such } \\
\text { as watching TV, chatting online, going online on Facebook, or } \\
\text { playing games than reading. }\end{array}$ & 4.23 & 0.88 & Very High \\
\hline
\end{tabular}




\begin{tabular}{|c|c|c|c|}
\hline Students attitude in total & 3.67 & 0.17 & High \\
\hline 2. Factors related to family support & $\bar{X}$ & S.D. & Interpretation \\
\hline 1. Everyone in my family supports me to read since I was young. & 4.04 & 1.07 & High \\
\hline 2. My parents keep telling me to read regularly. & 2.14 & 1.06 & Low \\
\hline $\begin{array}{l}\text { 3. My parents realize the benefits of English, so they usually bring } \\
\text { home English books. }\end{array}$ & 2.66 & 1.31 & Medium \\
\hline $\begin{array}{l}\text { 4. My parents are interested in my English } \\
\text { learning, especially scores from English courses. }\end{array}$ & 3.19 & 1.47 & Medium \\
\hline Family support in total & 3.01 & 0.19 & Medium \\
\hline
\end{tabular}

\begin{tabular}{|l|l|l|l|}
\hline 3. Factors related to teaching and learning in the classroom & \multicolumn{1}{|c|}{$\overline{\boldsymbol{X}}$} & S.D. & Interpretation \\
\hline $\begin{array}{l}\text { 1. I think that there should be more reading courses in the } \\
\text { curriculum of my faculty. }\end{array}$ & 3.80 & 1.16 & High \\
\hline $\begin{array}{l}\text { 2. I feel that I can practically use the contents from the reading } \\
\text { courses I studied. }\end{array}$ & 4.04 & 0.58 & High \\
\hline $\begin{array}{l}\text { 3. Activities in reading class are obsolete and not interesting. } \\
\text { 4. The instructor has good techniques in teaching reading, so it } \\
\text { helps students understand it and like reading. }\end{array}$ & 3.61 & 1.39 & High \\
\hline Teaching and learning in the classroom in total & 3.79 & 0.34 & High \\
\hline
\end{tabular}

Table 4.6 represents factors related to student's attitude of the 3rd year EIC students, statement number 7) I usually spend more leisure time on entertaining activities such as watching TV, chatting online, going online on Facebook, or playing games than reading was at a very high level $\left(x^{-}=4.23\right.$; S.D. $\left.=0.88\right)$ was at the highest level, followed by statement number 3$)$ I feel that ability to read English gives me a lot of benefits was at a high level $\left(x^{-}=4.19 ;\right.$ S.D. $\left.=1.03\right)$ was at a high level. Lastly, statement number 1) I like studying courses of English reading was at a medium level $\left(x^{-}=3.14 ;\right.$ S.D. $\left.=1.06\right)$. These showed that the 3rd year EIC students considered spending more time on social platforms was the most influential on their attitude, and studying English reading course is the less influential on their attitude. For factors related to family support, the 3rd year EIC students pointed out that statement number 1$)$ Everyone in my family supports me to read since I was young was at a high level $\left(x^{-}=4.04 ;\right.$ S.D. $\left.=1.07\right)$. On the contrary, statement number 2) My parents keeps telling me to read regularly was at a low level $\left(x^{-}=2.14 ; S D .=1.06\right)$ which revealed that they considered everyone in their family to support their reading as the most important factor and they recognized their parents keep telling them to read as the less important factor.

For factors related to teaching and learning in the classroom, the 3rd year EIC students indicated that statement number 2) I feel that I can practically use the contents from the reading course I studied was at a high level $\left(x^{-}=4.04\right.$; S.D. $\left.=0.58\right)$, and statement number 3) Activities in reading class are obsolete and not interesting was at a high level $\left(x^{-}=3.61\right.$; S.D. $\left.=1.39\right)$. These represented that the 3rd year EIC students thought they can practically use contents from the reading course they studied as the most significant factor and activities in reading class are obsolete and not interesting was their less significant factor on teaching and learning in the classroom.

Table 4.7: Factors of the reading problems that highly affect reading competence of 4th-year students of EIC 


\begin{tabular}{|c|c|c|c|}
\hline 1. Factors on student's attitude & $\overline{\boldsymbol{X}}$ & S.D. & Interpretation \\
\hline 1. I like studying courses of English reading. & 4.10 & 0.67 & High \\
\hline $\begin{array}{l}\text { 2. I like reading English from different kinds } \\
\text { of media such as newspaper magazines or the Internet. }\end{array}$ & 4.07 & 0.70 & High \\
\hline 3. I feel that ability to read English gives me a lot of benefits. & 4.25 & 0.63 & Very High \\
\hline 4. I can apply my knowledge to English reading. & 4.17 & 0.53 & High \\
\hline $\begin{array}{l}\text { 5. As I have a reading problem, I can employ } \\
\text { reading techniques to understand what I'm reading. }\end{array}$ & 3.82 & 0.60 & High \\
\hline $\begin{array}{l}\text { 6. I feel bored and lazy when I need to read any subject content } \\
\text { in English. }\end{array}$ & 3.14 & 0.87 & Medium \\
\hline $\begin{array}{l}\text { 7. I usually spend more leisure time on entertaining activities such } \\
\text { as watching TV, chatting online, going online on Facebook, or } \\
\text { playing games than reading. }\end{array}$ & 3.85 & 0.83 & High \\
\hline Students attitude in total & 3.91 & 0.10 & High \\
\hline 2. Factors on family support & $\overline{\bar{X}}$ & S.D. & Interpretation \\
\hline 1. Everyone in my family supports me to read since I was young. & 3.71 & 0.83 & High \\
\hline 2. My parents keep telling me to read regularly. & 3.35 & 1.17 & High \\
\hline $\begin{array}{l}\text { 3. My parents realize the benefits of English, so they usually bring } \\
\text { home English books. }\end{array}$ & 3.28 & 1.03 & High \\
\hline $\begin{array}{l}\text { 4. My parents are interested in my English learning, especially } \\
\text { scores from English courses. }\end{array}$ & 3.46 & 1.08 & High \\
\hline Family support in total & 3.45 & 0.14 & High \\
\hline
\end{tabular}

\begin{tabular}{|l|l|l|l|}
\hline 3. Factors on teaching and learning in the classroom & \multicolumn{1}{|c|}{$\overline{\boldsymbol{X}}$} & S.D. & Interpretation \\
\hline $\begin{array}{l}\text { 1. I think that there should be more reading courses in the } \\
\text { curriculum of my faculty. }\end{array}$ & 3.89 & 0.85 & High \\
\hline $\begin{array}{l}\text { 2. I feel that I can practically use the contents from the reading } \\
\text { course I studied. }\end{array}$ & 3.85 & 0.74 & High \\
\hline $\begin{array}{l}\text { 3. Activities in reading class are obsolete and not } \\
\text { interesting. }\end{array}$ & 3.50 & 0.90 & High \\
\hline $\begin{array}{l}\text { 4. The instructor has good techniques in teaching reading, so it } \\
\text { helps students understand it and like reading. }\end{array}$ & 3.75 & 0.57 & High \\
\hline Teaching and learning in the classroom in total & 3.75 & 0.14 & High \\
\hline
\end{tabular}

Table 4.7 revealed factors related to student's attitude of the 4th year EIC students, statement number 3) I feel that ability to read English gives me a lot of benefits was at a very high level $\left(\mathrm{x}^{-}=4.25\right.$; S.D. $\left.=0.63\right)$, followed by statement number 1$)$ I like studying 
courses of English reading was at a high level ( $x^{-}=4.10 ;$ S.D. $\left.=0.67\right)$. Lastly, statement number 6$)$ I feel bored and lazy when I need to read any subject content in English was at a medium level $\left(x^{-}=3.14\right.$; S.D. $\left.=0.87\right)$. These reflected that students' attitude was placed on the benefits of reading English, then they considered their preference of studying English reading course, they feel lazy when they need to read any subjects in English as their less important attitude.

The table also shows factors related to family support, statement number 1) Everyone in my family supports me to read since I was young was at a high level $\left(x^{-}=3.71\right.$; S.D. $\left.=0.83\right)$, then statement number 4$)$ My parents are interested in my English learning, especially scores from English courses was at a high level $\left(x^{-}=3.46\right.$; S.D. $\left.=1.08\right)$, lastly, statement number 3 ) My parents realize the benefits of English, so they usually bring home English books was at a high level $\left(x^{-}=3.28 ;\right.$ S.D. $=1.03$. These reflected that the 4th year EIC students considered everyone in their family supports their reading as the most important factor and they recognized their parents realize the benefits of English, so they usually bring home English books as the less important factor.

For factors related to teaching and learning in the classroom, the 4th year EIC students revealed that statement number 1) I think that there should be more reading courses in the curriculum of my faculty was at a high level $\left(x^{-}=3.89 ;\right.$ S.D. $\left.=0.85\right)$, followed by statement number 2) I feel that I can practically use the contents from the reading course I studied was at a high level $\left(x^{-}=3.85\right.$; S.D. $=0.74)$, lastly, statement number 3$)$ Activities in reading class are obsolete and not interesting was at a high level $\left(x^{-}=3.50\right.$; S.D. $=0.90$ ). These represented that the 4 th year EIC students thought they should be more reading courses in the curriculum of faculty as the most significant factor and activities in reading class are obsolete and not interesting was their less significant factor on teaching and learning in the classroom.

Table 4.8: The main reading problems and reading factors that highly affect EIC students' reading competence

\begin{tabular}{|l|l|l|}
\hline $\begin{array}{l}\text { Students' } \\
\text { group }\end{array}$ & Reading problems & $\begin{array}{l}\text { Factors influencing reading problems that } \\
\text { greatly } \begin{array}{c}\text { tect } \\
\text { affect } \\
\text { competence }\end{array}\end{array}$ \\
\hline 2nd & $\begin{array}{l}\text { Grammar: I don't understand English } \\
\text { sentence structure or grammar. }(\bar{x}=3.50 ; \\
\text { S.D. }=0.75)\end{array}$ & $\begin{array}{l}\text { Factors related to student's attitude }(\bar{x}=3.91 ; \\
\text { S.D. }=0.16)\end{array}$ \\
\hline 3rd & $\begin{array}{l}\text { Vocabulary: I don't know words or } \\
\text { expressions in the content I read. }(\bar{x}=3.19 ; \\
\text { S.D. }=0.66)\end{array}$ & $\begin{array}{l}\text { Factors related to teaching and learning in } \\
\text { classroom }(\bar{x}=3.79 ; \text { S.D. }=0.34)\end{array}$ \\
\hline 4th & $\begin{array}{l}\text { Vocabulary: I don't know words or } \\
\text { expressions in the content I read. }(\bar{x}=3.50 ;\end{array}$ & $\begin{array}{l}\text { Factors related to student's attitude }(\bar{x}=3.91 ; \text { S.D. } \\
=0.10)\end{array}$ \\
\hline
\end{tabular}

As shown in Table 4.8, EIC students in each group perceive reading problems and factors that affect their reading problems differently. In the 2 nd year group, grammar is seen to be their main reading problem ( $x^{-}=3.50 ;$ S.D. $=0.75$ ). Meanwhile, they consider that the factor students' attitude is the most influential factor toward their reading problems $\left(x^{-}=3.91 ;\right.$ S.D. $\left.=0.16\right)$. Moreover, the 3rd year EIC students pointed out that 'vocabulary' is their main reading problem $\left(x^{-}=3.19 ;\right.$ S.D. $\left.=0.66\right)$ and the factor they find the most influential to their reading problems is teaching and learning in the classroom $\left(x^{-}=3.79 ;\right.$ S.D. $\left.=0.34\right)$. Finally, the 4th year EIC students indicated that they have problems in reading with vocabulary as their main reading problem ( ${ }^{-}$ $=3.50$; S.D. $=0.87$ ) whereas they reveal that the factor 'students' attitude' does have the most impact on their reading problems $\left(x^{-}=3.91 ;\right.$ S.D. $\left.=0.10\right)$ respectively.

Table 4.9: Reading problems in total for 2nd, 3rd, and 4th year EIC students 


\begin{tabular}{|l|l|l|l|}
\hline Reading problems in total for 2nd, 3rd, and 4th year EIC students & $\overline{\boldsymbol{X}}$ & S.D. & Interpretation \\
\hline $\begin{array}{l}\text { Understanding: I don't understand the content and can't identify } \\
\text { important points of content. }\end{array}$ & 3.17 & 0.20 & Medium \\
\hline $\begin{array}{l}\text { Personal experience: The content being read isn't in my } \\
\text { knowledge area. }\end{array}$ & 3.13 & 0.04 & Medium \\
\hline $\begin{array}{l}\text { Vocabulary: I don't know words or expressions in the content I } \\
\text { read. }\end{array}$ & 3.37 & 0.11 & High \\
\hline $\begin{array}{l}\text { Grammar: I don't understand English sentence structure or } \\
\text { grammar }\end{array}$ & 3.28 & 0.16 & High \\
\hline
\end{tabular}

Table 4.9 shows total reading problems of $2 \mathrm{nd}$, $3 \mathrm{rd}$, and 4 th year EIC students. They considered vocabulary was at a high level $\left(\mathrm{x}^{-}\right.$ $=3.37$; S.D. $=0.11)$ followed by grammar was at a high level $\left(x^{-}=3.28 ;\right.$ S.D. $\left.=0.16\right)$, understanding was at a medium level $\left(x^{-}=\right.$ 3.17; S.D. $=0.20)$, and they last concerned was personal experience at a medium level $\left(x^{-}=3.13 ;\right.$ S.D. $\left.=0.04\right)$.

Table 4.10: Factors of the reading problems that highly affect reading competence in total for 2nd, 3rd, and 4th year EIC students

\begin{tabular}{|l|l|l|l|}
\hline $\begin{array}{l}\text { Factors of the reading problems that highly affect reading } \\
\text { competence in total for 2nd, 3rd, and 4th year ElC students }\end{array}$ & $\bar{X}$ & S.D. & Interpretation \\
\hline Factors related to student's attitude & 3.83 & 0.04 & High \\
\hline Factors related to family support & 3.27 & 0.04 & High \\
\hline Factors related to teaching and learning in the classroom & 3.68 & 0.10 & High \\
\hline
\end{tabular}

Table 4.10 shows factors of the reading problems that highly affect reading competence in total for $2 \mathrm{nd}$, $3 \mathrm{rd}$, and 4 th year EIC students. They reflected that Factors related to students' attitude were at a high level $\left(x^{-}=3.83 ;\right.$ S.D. $\left.=0.04\right)$, followed by factors related to family support were at a high level $\left(x^{-}=3.27 ;\right.$ S.D. $\left.=0.04\right)$, and they considered factors related to teaching and learning in the classroom with a high level $\left(x^{-}=3.68 ;\right.$ S.D. $\left.=0.10\right)$ was the less significant factor.

\subsection{Discussion}

Research on factors affecting reading comprehension problems of 2nd, 3rd, and 4th year EIC students at RMUTL Tak used questionnaire activities. The results can be discussed as follows.

According to the findings revealed in the present study, perceptions related to reading problems and factors affecting the EIC students in each group are completely varied. It could be seen that one minor reading problem of a group could become the main problem of another. For example, 2nd year EIC students pointed out that their main problem related to reading comprehension is grammar with a mean score of 3.50 which causes misspelling, and results in wrong word choice, verb form mistakes, and lack of subject-verb agreement. On the other hand, 3rd year EIC students revealed that vocabulary is their main problem when it comes to reading with a mean score of 3.19. Meanwhile, vocabulary is the main reading problem among 4th year EIC students as well, with a mean score of 3.50; this problem deprives them of meanings of words or phrases. The problem most found in the study was vocabulary. Other problems, such as understanding, grammar, and personal experience were found less frequently.

Different results were shown by Manatsawee Duangloy (2015). The sample for her study was 350 undergraduate students from 7 faculties in the Rajamangala University of Technology, Bangkok. In her research, she found that students could take an English reading comprehension test and get average points. The total is 3.37 points which can be considered in the relatively medium score range. This can be caused by many aspects, such as sentence reading skills, ability to capture important points, finding word meanings, or guessing words from context.

According to the results of this study, EIC students in each group had different opinions about their reading problems and factors related to their reading problems because most EIC students graduated from various kinds of high schools where English was 
taught in many different ways, and reading was taught differently in different schools. This could have an impact on students' reading problems and factors related to the reading problems that highly affect reading competence. For example, 2nd year EIC students pointed out that factors related to students' attitude with the mean score of 3.91 meant that students spent more leisure time on entertaining activities such as watching TV, going online on Facebook, or playing games than reading, whereas the 3rd year EIC students revealed that factors related to teaching and learning in the classroom are reading problems that highly affect reading competence with a mean score of 3.79 meaning students feel they can practically use the contents from their reading course. Meanwhile, factors related to students' attitudes are the main factors related to the reading problems among 4th year EIC students as well, with the mean score of 3.91. Factors related to the reading problems that highly affect reading competence found most in the study were students' attitudes. Other problems, such as teaching and learning in the classroom and family support, were found less frequently.

The results achieved in this study were found relevant to Manatsawee Duangloy (2015). The sample of her study were 350 undergraduate students from 7 faculties in the Rajamangala University of Technology in Bangkok. In her research, she found that students of the Rajamangala University of Technology Bangkok could take a questionnaire on factors related to reading problems.

\section{Conclusion of the Study}

This research aimed to examine the reading comprehension problems and investigate the main factors of the reading problems that greatly affected reading competence. Questionnaires were used to find reading problems and reading factors affecting EIC students' reading ability as the main participants.

According to the findings revealed in the study, perceptions related to reading problems and factors affecting the EIC students in each group were completely varied. The problem most found in the study was vocabulary. Other problems, such as understanding, grammar, and personal experience, were found less frequently. Also, the factor of reading problems in the study that highly affected reading competence most was students' attitude. Other problems, such as teaching and learning in the classroom and family support, were found less frequently.

According to the study, the reason why EIC students in each group had reading problems would be that most EIC students graduated from various kinds of high school backgrounds where English was taught in many different ways, as was the teaching of reading in different schools. This cause could have an impact on students' reading problems and their perceptions of factors they thought to influence their reading problems. Ulfa (2012) stated that there were students who did not have good motivation to read and they felt the text was not interesting for them because they must keep looking up words in a dictionary to find out their meanings. These activities make them feel bored and uninterested in reading comprehension. Therefore, it was a problem for the teacher in teaching reading comprehension in the class.

However, to solve reading problems, a plan needs to be constructed to build students' fundamental reading skills which can appropriately improve learning to read at the tertiary level. A university or school can cope with students reading problems by managing a pedagogical plan that focuses on providing essentially fundamental levels of reading skills or giving a reading test to assess students' reading proficiency at the beginning as well as eliciting reading difficulties the students might encounter. Therefore, an instructor would be able to set a proper teaching method for reading, including appropriate reading materials suitable for a particular group of students' reading levels. Alderson (2000) says they naturally cannot adjust to the increased and varying demands of reading at higher levels. Some are even without adequate facilities in the mechanics of reading (word recognition); others possess this but have not acquired such skills as finding the topic of the reading passage. Others may have acquired the fundamental reading skills but have never had training or practice in the efficient use of them. Because of these deficiencies, remedial or corrective instruction is necessary to help students succeed in their studies. However, before finding a method to help them, their abilities and their problems need to be known.

In addition, in the study conducted with three groups of EIC students at RMUTL Tak, there are comments related to their reading problems and reading factors that the students additionally provided, such as reading technique. Some students did not have much vocabulary or grammar knowledge or some of them did not have techniques to interpret what they were reading.

\subsection{Suggestions for further research}

1. The future and possible study should explore the needs of students for English reading courses, as well as English language or activity guidelines that encourage the development of English reading skills.

2. The future and possible study should investigate additional problems in English language studies such as writing or speaking, which are important skills and can cause problems for students as well.

3. The future and possible study should articulate students' attitudes towards the teaching and learning of English courses related to reading skills at the university.

\section{References}


[1] Anderson, R. C. (1985). Role of Reader's schema in Comprehension. Learning and Memory In Theoretical Models and Process of Reading, Delaware: International Reading Association.

[2] Alderson, J. (2000). Assessing reading. New York: Cambridge University Press.

[3] Atnondla S., (2006). Development of knowledge base for reading English for the group of learning foreign languages (English), 4 years, Kasetsart University.

[4] Bond, G.L., and M.A. Tinker. (1979). Reading-Difficulties. New Jersey: Prentice-Hall.

[5] Chaiwasu R. (1988). Teaching and learning problems among students majoring in English at the bachelor's degree level in the faculty of education and education at closed universities Bangkok. Master's thesis. Kasetsart University.

[6] Duffy, G., \& Roehler, L. (1993) Helping students use comprehension strategies: process goals. Improving Classroom Reading Instruction. 3rd ed. New York: Mc Graw -Hill, Inc.

[7] Esky, D.E. (1986). Theoretical Foundations in Teaching Secondary Language Reading for Academic Purposes. Massachusetts: Addison Wesley.

[8] Goodman, (1988). The Reading Process. In Interactive Approaches to Second Language Reading. Cambridge University.

[9] Gray, W.S. (1960). The major aspects of reading in Sequential development of reading abilities. 8-24. Chicago University Press. Chicago.

[10] Harris, J. Albert, and Edward R. S. (1990). How to Increase Reading Ability. Longman England Cliffs: Prentice-Hall.

[11] Harris, L. A., and Smith, C. B. (1980). Reading Instruction Diagnostic Teaching in the Classroom. New York: Holt, Rinehart, and Winston.

[12] Hock, M., \& Mellard, D.F. (2005). Reading comprehension strategies for adult literacy outcomes, Journal of Adolescent \& Adult Literacy, 49(3): 192-200.

[13] Pruksawan B. (1989). A new dimension in teaching reading. Bangkok: Thai Wattana Panich.

[14] Richek, M.\& Caldwell. (1996). Reading problems assessment and teaching strategies. Boston: Allyn \& Bacon.

[15] Rosenblatt H,L. (1983). Literature as exploration. (4th ed.). Modern Language Association. New York

[16] Rungsanyangkun P. (1987). Reading in English. Department of English Language and Linguistics. Bangkok: Ramkhamhaeng University.

[17] Sanphak S. (2009). Reading problems. Retrieved from http://www.gotoknow.org/.

[18] Senchaowanich S. (1987). Techniques for reading English for comprehension. Bangkok: Thammasat University.

[19] Tangthawee S. (1986). Practical language usage. Bangkok: Odeon Store.

[20] Ulfa S. (2012). Improving Students' Achievement in Reading Comprehension Through Learning Together Method. FBS Unimed.

[21] Williams, E. (1993). Reading in the Language Classroom.: The Macmillan Publishers: London.

[22] Yimwilai S. (2008). English Reading Abilities and Problems of English-major Students Srinakharinwirot University. Srinakharinwirot University. 